\title{
Mating patterns and contemporary gene flow by pollen in a large continuous and a small isolated population of the scattered forest tree Sorbus torminalis
}

\author{
SE Hoebee ${ }^{1,3}$, U Arnold ${ }^{1,2}$, C Düggelin ${ }^{1,2}$, F Gugerli ${ }^{1}$, S Brodbeck ${ }^{1}$, P Rotach ${ }^{2}$ and R Holderegger ${ }^{1}$ \\ ${ }^{1}$ WSL Swiss Federal Research Institute, Birmensdorf, Switzerland and ${ }^{2}$ Department of Environmental Sciences, Swiss Institute \\ of Technology ETH, Zürich, Switzerland
}

\begin{abstract}
The influence of population size and spatial isolation on contemporary gene flow by pollen and mating patterns in temperate forest trees are not well documented, although they are crucial factors in the life history of plant species. We analysed a small, isolated population and a large, continuous population of the insect-pollinated tree species Sorbus torminalis in two consecutive years. The species recently experienced increased habitat fragmentation due to altered forest management leading to forests with closed canopies. We estimated individual plant size, percentage of flowering trees, intensity of flowering, degree of fruiting and seed set per fruit, and we determined mating patterns, pollen flow distances and external gene flow in a genetic paternity analysis based on microsatellite markers. We found clear effects of small population size and spatial isolation in S. torminalis. Compared
\end{abstract}

with the large, continuous population, the small and isolated population harboured a lower percentage of flowering trees, showed less intense flowering, lower fruiting, less developed seeds per fruit, increased selfing and received less immigrant pollen. However, the negative inbreeding coefficients $\left(F_{I S}\right)$ of offspring indicated that this did not result in inbred seed at the population level. We also show that flowering, fruiting and pollen flow patterns varied among years, the latter being affected by the size of individuals. Though our study was unreplicated at the factor level (i.e. isolated vs non-isolated populations), it shows that small and spatially isolated populations of $S$. torminalis may also be genetically isolated, but that their progeny is not necessarily more inbred.

Heredity (2007) 99, 47-55; doi:10.1038/sj.hdy.6800962; published online 2 May 2007

Keywords: fecundity; mate availability; paternity analysis; pollen flow distance; pollen immigration; selfing rate

\section{Introduction}

Pollen flow distance, either as pollen dispersed within populations or as gene flow among populations, is important in evolution, ecology and conservation (Barrett and Harder, 1996; Burczyk et al., 2004). Plant mating patterns, as mediated by pollen flow, are primary determinants of the level of genetic variation within populations and of how this variation is distributed among populations. Mating and pollen flow patterns are affected by several population parameters including population size and spatial isolation (Young et al., 1996; Sork et al., 1999) and by individual parameters such as plant size, floral display or flowering phenology (Barrett and Harder, 1996).

Habitat fragmentation and deterioration impact on mating patterns, both at the population and the individual levels. While fragmentation per se, leading to increased geographical isolation and decreased connec-

Correspondence: Dr R Holderegger, WSL Swiss Federal Research Institute, Zürcherstrasse 111, CH-8903 Birmensdorf, Switzerland.

E-mail: rolf.holderegger@wsl.ch

${ }^{3}$ Current address: Plant Cell Biology Research Centre, School of Botany, University of Melbourne, Victoria 3010, Australia.

Received 8 August 2006; revised 14 December 2006; accepted 16 February 2007; published online 2 May 2007 tivity, influences the amount of gene flow among remnant populations, the associated loss in habitat area (Fahrig, 1997) causes a reduction in population size, restricting the number of local mating partners (Young et al., 1996; Sork et al., 1999). Furthermore, decrease in habitat quality is associated with less favourable environmental conditions in remnant populations (Frankham et al., 2002), potentially causing a reduction in individual size and floral display. The latter affects pollen flow patterns within populations, which can in turn lower fecundity and fitness (Allee effects; Lienert, 2004; Willi and Fischer, 2005). Hence, pollen flow patterns are a key factor in plant conservation and genetics.

In Central Europe, traditionally managed forest habitats such as pasture woodlands, coppiced woodlands or coppiced forests with standards have dramatically declined during the last century due to recent management regimes favouring high forests with closed canopies (Bradshaw, 2004). This process has led to reduced habitat area and quality and, at the same time, increased fragmentation of pioneer or early successional trees that depend on sparse woodland sites. Among these species are many of Europe's rare insect-pollinated, fleshy-fruited deciduous trees such as service trees (Sorbus spp.), wild pear (Pyrus pyraster) or wild apple (Malus sylvestris). The distribution patterns of these 
species were originally scattered in the natural landscape, but the traditional human forest management since medieval ages has favoured these light-demanding forest species (Wohlgemuth et al., 2002). Species with naturally scattered distributions and naturally small population sizes are assumed to be better adapted to the potential detrimental effects of small population size and fragmentation to population viability, such as increased inbreeding (Huenneke, 1991; Holderegger, 1997). However, even for such species, the abovementioned recent disruption of long-established population networks or metapopulations may have led to alterations in gene flow and mating patterns.

Genetic paternity analysis is the current method of choice for direct investigations of contemporary pollen flow in plants (for alternative approaches see Sork and Smouse (2006); for potential methodological difficulties see Burczyk and Chybicki (2004)). Recent studies (reviewed in Sork et al., 1999; Burczyk et al., 2004; Hamrick, 2004; Smouse and Sork, 2004; Ward et al., 2005; Sork and Smouse, 2006) show that in insect-pollinated trees, pollen flow distances are often long, exceeding hundreds of metres or even kilometres and that pollen immigration into populations averages about $30 \%$. However, most of the corresponding studies have been carried out on tropical trees (Hamrick, 2004; Smouse and Sork, 2004; Ward et al., 2005), while studies on contemporary gene flow in temperate insect-pollinated tree species are still scarce (Burczyk et al., 2004; for early studies on temperate wind-pollinated trees see Dow and Ashley, 1996 and Streiff et al., 1999). One particular exception is Europe's wild service tree, Sorbus torminalis, which has been intensively studied, both with respect to its population dynamics at larger geographical scales (Demesure et al., 2000; Oddou-Muratorio et al., 2001a, b; Angelone et al., in press), as well as to its contemporary gene flow by pollen at the local scale (Oddou-Muratorio et al., 2003, 2005). However, no study examined the influence of population size and fragmentation on current patterns of gene flow by pollen in this rare and scattered forest tree.

The aim of the present study was to investigate contemporary pollen flow and mating patterns in two populations of $S$. torminalis contrasting in their size and degree of spatial isolation. We coupled genetic data with ecological data on individual size, flowering, fruiting and seed set and asked the following question: (1) Is flowering intensity, fruiting and seed set decreased in the smaller population as could be expected if the habitat of the latter is less favourable than that of the larger population? (2) Do individuals in the smaller population mate with fewer partners than individuals in the larger population, and does this potential mate limitation result in a higher degree of selfing and inbreeding in the smaller population? (3) Does spatial isolation lead to a decreased rate of pollen immigration, that is reduced gene flow among populations?

\section{Materials and methods}

\section{Study species}

S. torminalis (L.) Crantz (Rosaceae) is a pioneer or early successional forest tree that colonizes disturbed forest patches and forest edges. It is widely distributed in southern, western and central Europe (Warburg and Kàrpàti, 1968), but rarely dominates forests and never occurs in pure stands (Kutzelnigg, 1995). The species often grows in dry and sparse forest habitats of low productivity and on steep slopes. Formerly, many of these forests were coppiced and/or grazed, which led to an indirect favouring of the light-demanding $S$. torminalis (Barengo et al., 2001). Nowadays, these stands have been converted into forests with closed canopies dominated by late successional species, especially Quercus spp. and Fagus silvatica. Consequently, habitat conditions have become less favourable for the establishment and persistence of $S$. torminalis, leading to increased fragmentation of this species' remnant populations.

S. torminalis is described as diploid ( $2 n=34$; Liljefors, 1955) and shows clonal growth (Hoebee et al., 2006). The species produces large displays of white, hermaphrodite and unspecialized entomophilous flowers in spring, which are visited by various insects including bees, bumblebees, butterflies, hoverflies and beetles (OddouMuratorio et al., 2005). Its berries are dispersed by birds or frugivorous mammals (Demesure et al., 2000; OddouMuratorio et al., 2001a, b). In Central Europe, populations of $S$. torminalis are scattered, often small ( $<100$ individuals) and spatially isolated (Barengo et al., 2001).

\section{Study sites}

The first population Bremlen (Figure 1) is part of a large, more or less contiguous series of stands of $S$. torminalis in the Canton of Schaffhausen in north-eastern Switzerland

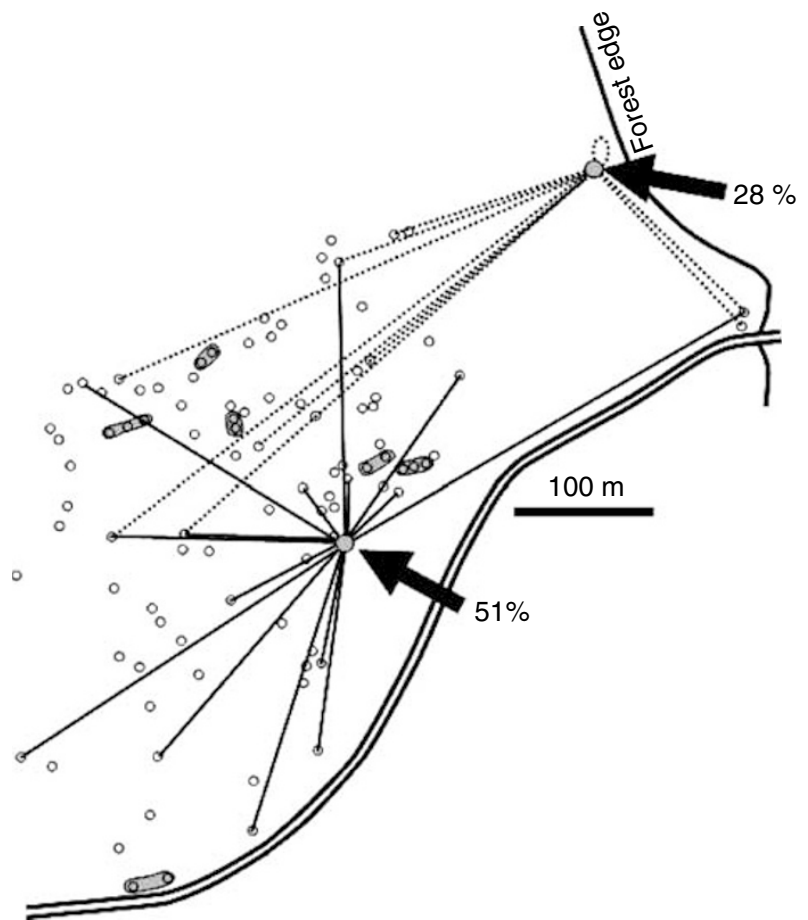

Figure 1 Examples of pollen flow among $S$. torminalis trees (open small circles) within the large, continuous Swiss population Bremlen in 2001. Straight black and dotted lines refer to pollen flow from father trees to either of two mother trees (large grey circles) within the population, and the curved dotted line refers to selfing. Large black arrows indicate pollen immigration (gene flow) from outside the study area. Grey polygons represent clones. 


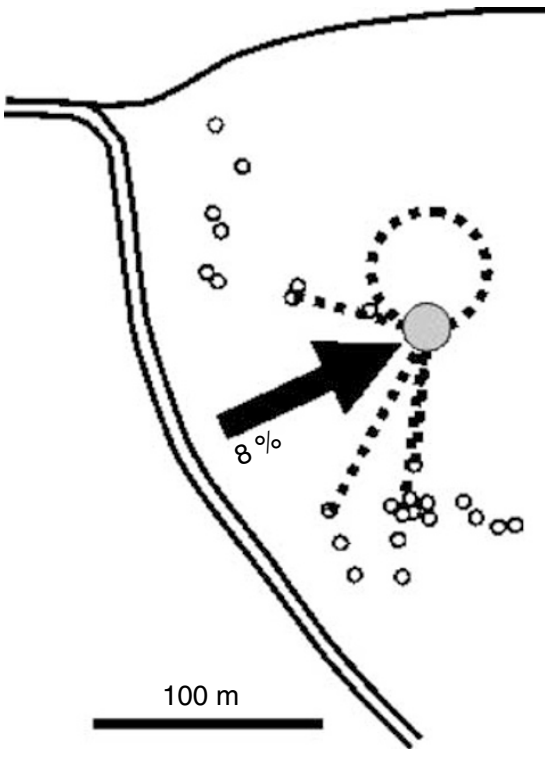

Figure 2 Example of pollen flow among $S$. torminalis trees (open small circles) within the small, isolated Swiss population Wuerholz in 2001. Straight dotted lines refer to pollen flow from father trees to one mother tree (large grey circle) within the population, and the curved dotted line refers to selfing. The large black arrow indicates pollen immigration (gene flow) from outside the study area.

$\left(47^{\circ} 43^{\prime} 48^{\prime \prime} \mathrm{N} / 8^{\circ} 38^{\prime} 42^{\prime \prime} \mathrm{E}, 540 \mathrm{~m}\right.$ asl). The surveyed area consisted of about 18 ha of formerly coppiced woodland with standards. It is bounded by continuous forests on three sides and by agricultural fields on the other. A total of $96 \mathrm{~S}$. torminalis individuals with a diameter at breast height $(\mathrm{DBH})$ of more than $6 \mathrm{~cm}$ occurred across the study area.

The second population Wuerholz (Figure 2), also in northeastern Switzerland (Canton Thurgau, $47^{\circ} 32^{\prime} 17^{\prime \prime} \mathrm{N} /$ $8^{\circ} 54^{\prime} 03^{\prime \prime} \mathrm{E}, 460 \mathrm{~m}$ asl) grows on a gentle slope in a closed canopy forest and occupies an area of about 2 ha. The population census size was 27 individuals $(\mathrm{DBH}>6 \mathrm{~cm})$. This small population was spatially isolated, with a single, isolated adult tree at a distance of $400 \mathrm{~m} \mathrm{NE}$, a small group of $S$. torminalis with only one adult individual $1250 \mathrm{~m} \mathrm{~W}$ and the closest population of $S$. torminalis at $6 \mathrm{~km} \mathrm{E}$ (Barengo et al., 2001).

\section{Field measurements}

We recorded the position and the DBH of all S. torminalis trees in the two populations. Since it is difficult to estimate flowering and fruiting in forest trees, only qualitative measurements were taken (Oddou-Muratorio et al., 2005). From May to June 2001 and 2002, flowering was monitored for about half of the trees in Bremlen $(n=46)$ and for all trees in Wuerholz $(n=27)$ once per week. The following phenological stages were recorded: (1) flower buds closed; (2) start of flowering, less than 5\% of flowers open; (3) less than $30 \%$ of flowers open; (4) peak flowering, more than $30 \%$ of flowers open; (5) end of flowering, more than $80 \%$ of flowers withered. Fruiting was recorded for the same trees at the end of September 2001 and 2002. The following fruiting categories were used: (1) $0 \%$, (2) $1-5 \%$, (3) $6-25 \%$, (4) $26-60 \%$ and (5) $60-100 \%$ of the tree crown covered with fruits.
DNA extraction and microsatellite genotyping

We collected fresh leaf material from all trees in the two populations. Open pollinated fruits (for progeny analysis and seed set data) were sampled from the ground below the individual canopy or directly from the tree of 13 individuals in 2001 and of four individuals in 2002 in Bremlen and from three individuals in Wuerholz in 2001. Because fruiting strongly varied between years (see 'Results' section), no consistent data set could be obtained. For instance, no trees produced sufficient fruits with developed seeds for progeny analysis in Wuerholz in 2002. The number of seeds analysed per mother tree (one seed per fruit) also varied substantially (range 11-48).

For genotyping adult trees, $50 \mathrm{ng}$ of frozen plant material was lyophylized, placed in liquid nitrogen for $10 \mathrm{~min}$ and disrupted using a Mixer Mill MM 300 (Retsch, Haan, Germany). For paternity analysis, embryos (including cotyledones; total $=824$, mean $=41.5$ ) were carefully excised from the seed coat and endosperm on a cooling plate, placed in Eppendorf tubes, lyophylized and disrupted as described above. During the preparation of seeds for DNA extraction, the number of developed seeds per fruit was determined. DNA extraction was carried out with the DNeasy 96 Plant kit (Qiagen, Hombrechtikon, Switzerland) with the minor modification of DNA being washed twice. The extracted DNA was quantified against lambda DNA on $1 \%$ agarose gels in $1 \times$ TrisBorate-EDTA buffer and stained with ethidium bromide.

Five microsatellite primer pairs (Oddou-Muratorio et al., 2001c) were used for genotyping. The primer pairs MSS1 (NED), MSS5 (HEX), MSS6 (FAM), MSS9 (HEX) and MSS16 (FAM), each with one primer being fluorescently labelled, were used in separate $12.5 \mu$ l polymerase chain reaction $(P C R)(1 \times$ PCR buffer (Sigma-Alderich, Buchs, Switzerland), $1.5 \mathrm{mM} \mathrm{MgCl}_{2}, 200 \mu \mathrm{M}$ of each dNTP, $0.2 \mu \mathrm{M}$ of each primer, $0.75 \mathrm{U}$ Taq-polymerase (Sigma), $2 \mathrm{ng}$ genomic DNA and $\mathrm{dd}_{2} \mathrm{O}$ ). Amplification was performed with an initial denaturing step of $94^{\circ} \mathrm{C}$ for $4 \mathrm{~min}$, followed by 35 cycles at $94^{\circ} \mathrm{C}$ for $45 \mathrm{~s}$, annealing at $60^{\circ} \mathrm{C}$ (MSS1 and MSS5) or $57^{\circ} \mathrm{C}$ (MMS6, MSS9 and MSS16) for $45 \mathrm{~s}$ and elongation at $72^{\circ} \mathrm{C}$ for $60 \mathrm{~s}$, with a final extension at $72^{\circ} \mathrm{C}$ for $30 \mathrm{~min}$ on MJ Research (Waltham, MA, USA) thermocyclers. Two groups of multiplexed PCR products were separated using an ABI PRISM 377 DNA Sequencer (Applied Biosystems, Rotkreuz, Switzerland). The first contained $0.5 \mu \mathrm{l}$ of PCR product of each of the loci MSS1, MSS5 and MSS6, while the second comprised $0.5 \mu \mathrm{l}$ of each of MSS9 and MSS16. The sizes of the amplified fragments were determined against an internal size standard (ROX 400HD; Applied Biosystems) with GENESCAN (Applied Biosystems). GENOTYPER version 2.5 (Applied Biosystems) was used to assign genotypes.

\section{Statistical analyses}

We performed the statistical analyses at the population level, since we were mainly interested in differences between the large, continuous and the small isolated population of $S$. torminalis. In all analyses, we excluded ramets of the same genet, except the one with the largest DBH.

We compared the ranking order at peak flowering and the ranking order in fruiting of those trees that flowered 
and/or set fruit in both years with Wilcoxon signed-rank tests in both populations. We analysed differences of trees that set fruit with Mann-Whitney tests per year among populations. Additionally, the relationship between DBH (normally distributed) and flowering (yes/ no) was analysed in a log-linear regression of the combined data set for both populations and years. Differences in mean seed set per fruit per tree between the two populations in 2001, as well as differences in mean seed set per fruit per tree between 2001 and 2002 in Bremlen, were analysed with an unpaired and a paired $t$-test, respectively (normally distributed data).

FSTAT 2.9.3 (J Goudet, University of Lausanne) was used to calculate inbreeding coefficients $\left(F_{\mathrm{IS}}\right)$ per locus of adult populations and corresponding progenies. Significant deviations from zero, as well as differences between adults and progenies per population and between the adult populations Bremlen and Wuerholz, were determined with 1000 permutations in FSTAT. Tests of biparental inbreeding (Ritland, 2002) were performed by comparing the single-locus ( $t s)$ and the multi-locus $(\mathrm{tm})$ outcrossing rates in MLTR 3.0 (K Ritland, University of British Columbia, Vancouver) using 1000 bootstraps.

Paternity was assigned using CERVUS 2.0 (Marshall et al., 1998). Standard simulation parameters were used with 10000 cycles including all adult trees per population (candidate parents), thus allowing for selfing. Genotyping error rate was set at zero, following Oddou-Muratorio et al. (2003) and Slavov et al. (2005). The minimum number of loci required for paternity analyses was set to four. There was no indication of null alleles at the five loci investigated (also see negative $F_{\text {IS }}$ values of progenies given in the 'Results' section). Three classes of assignment were recorded: (1) paternity: unambiguous assignment to a single known father tree with confidence $\geqslant 80 \%$; (2) within population mating: paternity assigned to several father trees within the population with equal likelihood; (3) gene flow by pollen: no father tree identified within the population, that is pollen-mediated gene flow from outside the population.

The number of mother trees mating with a given father tree relative to the total number of mother trees analysed in a particular year and the relative contribution of father trees to the progeny of a given mother tree were determined. Differences of these values between 2001 and 2002 in Bremlen, as well as between Wuerholz and Bremlen in 2001, were tested with Mann-Whitney tests (data not normally distributed). The same tests were applied to pollen flow distances, mean selfing rate and mean gene flow rate per mother tree as well as the absolute number of father trees per mother tree in Bremlen in 2001 and 2002 and between Bremlen and Wuerholz in 2001. The relative paternal contribution to the progeny of a given mother tree in relation to the inter-parent distance and $\mathrm{DBH}$ of the father tree was tested in a stepwise multiple regression analysis with backward selection per population and year (residuals normally distributed).

All standard statistical tests were carried out using SPSS version 10.00 (SPSS, Chicago, IL, USA). Significance thresholds for all multiple comparisons (e.g., comparisons between adult populations and between adult populations and their respective progenies from different years) were adjusted according to the sequential Bonfer- roni method (Rice, 1989), and normal distribution of data was checked with Kolmogoroff-Smirnoff tests.

\section{Results}

\section{Flowering, fruiting and seed set}

Flowering time and fruit production were variable within populations among years, with population Wuerholz flowering about 1 week later than population Bremlen. In the large, continuous population Bremlen, about $70 \%$ of trees flowered in both years, but flowering time was less synchronous in 2001 than in 2002. Only $60 \%$ of the surveyed trees in Bremlen flowered in both years. The flowering period extended over 18 and 20 days, respectively. In the small and isolated population Wuerholz, about $50 \%$ of trees flowered in 2001, but only $30 \%$ did so in 2002. Here, flowering was more asynchronous among individuals in both years. However, in both years and both populations, the flowering period of all individuals did overlap to a certain degree. The ranking order of trees in peak flowering among the two study years was not different in both populations.

The smallest individual that flowered had a DBH of $10 \mathrm{~cm}$. Larger trees had a higher probability of flowering; however, even trees with large diameters did not necessarily flower. Accordingly, log-linear regression showed a significant, but rather weak correlation between $\mathrm{DBH}$ and flowering $(\beta=0.17$, Wald statistics $P=0.001$ ). Only large trees with a $\mathrm{DBH} \geqslant 35 \mathrm{~cm}$ had a $95 \%$ probability of flowering. Fruiting was greater in 2001 than in 2002, but only significantly so in Bremlen $(P=0.001)$. In 2001, $70 \%$ of the trees in Bremlen set fruit, most with more than $5 \%$ of their crown covered with fruits. In contrast, only $52 \%$ of the trees in Bremlen set fruit in 2002, with mostly less than $5 \%$ of crown covered with fruits. Only 27 and $11 \%$ of the trees in Wuerholz set fruit in 2001 and 2002, respectively. Some trees that flowered did not set any fruit at all in both populations. Fruiting significantly differed between Bremlen and Wuerholz in $2001(P=0.024)$, but not so in 2002 .

A maximum of five developed seeds per fruit was found, but mean seed set per fruit per mother tree was much lower in both populations. One tree in Wuerholz produced numerous fruits, but none of the several hundred fruits examined contained developed seeds. This indicates that fruit set per se is not a good indicator of individual fecundity, mating success or fitness in S. torminalis. In Bremlen, mean seed set per fruit was $1.28 \pm 0.16$ (s.e.) in 2001 and $0.6 \pm 0.17$ in 2002, with the difference being statistically significant $(P=0.015)$. In Wuerholz, only data for 2001 were available (see 'Materials and methods' section), and the mean seed set per fruit per mother tree was low with only $0.17 \pm 0.11$. In 2001, mean seed set per fruit per mother tree was significantly different between the two populations $(P=0.001)$

\section{Inbreeding and clones}

In Bremlen, inbreeding coefficients were significantly different from zero in the adults $\left(F_{\mathrm{IS}}=0.04, P=0.032\right)$, but not so in the progenies (2001 and $2002 F_{\mathrm{IS}}=-0.03$ ). In Wuerholz, the inbreeding coefficients were negative in the adults $\left(F_{\mathrm{IS}}=-0.10\right)$ and the 2001 progeny $\left(F_{\mathrm{IS}}=-0.04\right)$, but both did not significantly differ from 
zero. The $F_{\mathrm{IS}}$ values of adults and progenies were not different from each other in both populations and both years. Note that all progenies from both populations had slightly negative $F_{\text {IS }}$ values. The two adult populations differed significantly $(P=0.032)$ in their $F_{\mathrm{IS}}$, but the difference became non-significant when the significance threshold was adjusted for multiple comparisons (sequential Bonferroni; Rice, 1989). Multi-locus estimates of outcrossing rate $(\mathrm{tm})$ were 0.98 in Bremlen 2001, 0.93 in Bremlen 2002 and 0.78 in Wuerholz 2001. In all cases, there were no significant differences between $\mathrm{tm}$ and $t s$ (the single-locus outcrossing rate), indicating the absence of bi-parental inbreeding.

Few clones (spatially aggregated recurring multi-locus genotypes) were observed in the present study. While seven small clones of only two or three ramets were observed in Bremlen, no clone was found in Wuerholz (Figures 1 and 2).

\section{Paternity analyses}

Total exclusion probability for paternity assignment was $\geqslant 0.992$ in Bremlen in both years and 0.946 in Wuerholz in 2001. A single-father tree within population (with a confidence of $\geqslant 80 \%$ ) could be assigned to $52.3 \%$ of the seeds analysed in Bremlen in 2001 and to $51.6 \%$ in 2002. The corresponding value was $60.6 \%$ for Wuerholz in 2001. Paternity assignment with several individuals within population being equally likely to have sired a given seed accounted for $11.4 \%$ in 2001 and $9.1 \%$ in Bremlen in 2002 and for $31.8 \%$ in Wuerholz in 2001.

In Bremlen, many father trees contributed to the seed arrays analysed in both years, 56 in 2001 and 33 in 2002, and the number of mother trees fertilized by a given father tree (without selfing) relative to the total number of mother trees analysed in a particular year significantly varied between years $(P=0.002)$. This latter parameter had a mean of $0.22 \pm 0.02$ and of $0.36 \pm 0.07$ in Bremlen in 2001 and 2002, respectively. The inter-annual variation at the individual level can be illustrated by two trees that sired 19 and 17 seeds, respectively, in 2001, but did not sire any seed in 2002. In Wuerholz, the mean contribution of the nine observed father trees was $0.32 \pm 0.08$ in 2001 . This mean value was significantly different from that in Bremlen $(P=0.002)$ in 2001.

The ovules of the mother trees analysed in Bremlen in 2001 were fertilized by an average of $12.46 \pm 0.94$ father trees (without selfing), with a minimum of 8 and a maximum of 19 father trees. The corresponding values in 2002 were $12.25 \pm 2.8,5$ and 18 father trees per mother tree. The mean values did not statistically differ between years. In the small isolated population Wuerholz, we observed a mean of $4.66 \pm 0.67$ father trees per mother tree, with a minimum of four and a maximum of six father trees. The difference between the two populations was significant in $2001(P=0.008)$.

Mean self-fertilization, $2.0 \%$ in 2001 and $7.6 \%$ in 2002, was moderate in Bremlen. The highest level of selfing (6.3\%) was observed in a spatially isolated tree at the forest edge, $150 \mathrm{~m}$ away from the nearest $S$. torminalis tree within the population (Figure 1). In Wuerholz, mean selffertilization accounted for substantial $29.3 \%$ in 2001. This estimate was dominated by one individual with a selfing rate of $53.8 \%$. The mean selfing rates significantly differed between populations in $2001(P=0.008)$.

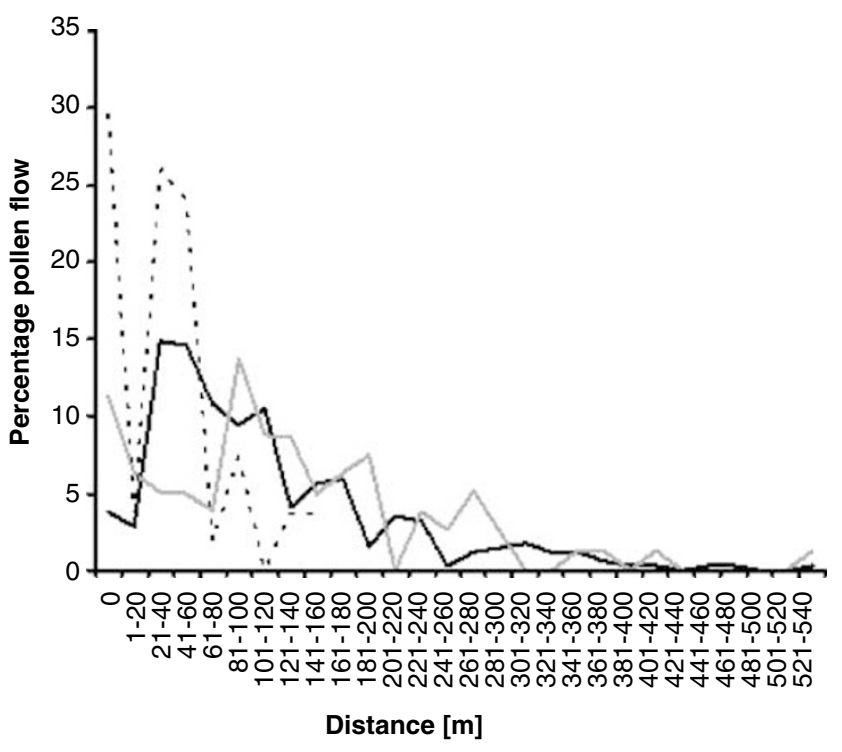

Figure 3 Pollen flow distances within two Swiss populations of $S$. torminalis. Black line: large, continuous population Bremlen in 2001; grey line: population Bremlen in 2002; dotted line: small, isolated population Wuerholz in 2001. Values at zero distance indicate the overall selfing rate at the seed level.

The father trees of a given mother tree were usually scattered over the population area, with the closest $S$. torminalis trees not necessarily being the most successful sires (Figure 1). The maximum distance between two mates in Bremlen was 528 and $526 \mathrm{~m}$ in 2001 and 2002, respectively, that is, almost the maximum potential distance between two trees within the studied population (Figure 1). Pollen flow distances (excluding selfing) within Bremlen statistically differed $(P=0.01)$ in the two study years, with means of $119.40 \pm 5.37 \mathrm{~m}$ (median $=90 \mathrm{~m})$ in 2001 and $148.3 \pm 11.85 \mathrm{~m}($ median $=133 \mathrm{~m})$ in 2002 (Figure 3). Pollen travelled a mean distance of $59.24 \pm 5.96 \mathrm{~m} \quad($ median $=57 \mathrm{~m})$ in Wuerholz in 2001 (Figure 3), with a maximum of $158 \mathrm{~m}$. This latter value was again consistent with the maximum distance attainable within the population (Figure 2). Mean pollen flow distances were significantly different between the populations in $2001(P=0.001)$. Figure 3 also illustrates that pollen dispersal was not exponential.

The relative contribution of father trees to the progeny of a given mother tree $(0.22 \pm 0.02)$ depended on both the inter-parent distances and their DBH in Bremlen in 2001 (Table 1). This means that, in 2001, larger trees that were closer to a given mother tree had a higher siring success than smaller trees that were more distant. However, the regression analysis only explained $9.6 \%$ of the variation in the data (Table 1). In 2002, only DBH, but not distance, was significantly associated with relative siring success in Bremlen $\left(0.31 \pm 0.07 ; R^{2}=8.8 \%\right)$. Similarly, only DBH significantly influenced the siring contribution of father trees $\left(0.52 \pm 0.07 ; R^{2}=57.3 \%\right)$ in Wuerholz in 2001 (Table 1). Relative siring success was not different between years in Bremlen, but differed significantly between the studied populations in $2001(P=0.008)$. In summary, distance among mating partners had a low impact on siring success, while DBH exhibited a larger effect. 
Table 1 Stepwise regression with backward selection of the relative contribution of father trees to the progeny of a given mother tree in relation to inter-parental distance and paternal DBH in two Swiss populations of S. torminalis (2 years: 2001 and 2002, in population Bremlen; and 1 year: 2001, in population Wuerholz)

\begin{tabular}{lccc}
\hline Population and year & Model & Distance & DBH \\
\hline Bremlen 2001 & $R^{2}=0.096, P=0.001$ & $\beta=-0.214, P=0.008$ & $\beta=0.167, P=0.037$ \\
Bremlen 2002 & $R^{2}=0.088, P=0.041$ & - & $\beta=0.296, P=0.041$ \\
Wuerholz 2001 & $R^{2}=0.573, P=0.003$ & - & $\beta=0.757, P=0.003$ \\
\hline
\end{tabular}

Abbreviations: $\mathrm{DBH}$, diameter at breast height; $R^{2}$, determination coefficient; $\beta$, standardized partial correlation coefficient.

Mean gene flow from outside (i.e. pollen immigration) in the large, continuous population Bremlen was not significantly different in $2001(36.97 \pm 4.04 \%)$ and 2002 $(38.65 \pm 7.45 \%)$, but it significantly differed between the large, continuous population Bremlen and the small, isolated population Wuerholz $(3.7 \pm 2.23 \%)$ in 2001 $(P=0.008)$. To the maximum, one tree in Bremlen 2002 received $60.9 \%$ siring pollen from outside the population.

\section{Discussion}

\section{Variation among years}

We found considerable variation in flowering, fruiting and seed set among years in a small, spatially isolated and a large, continuous population of S. torminalis. In both populations, the number of flowering trees, flowering intensity and fruiting were all greater in 2001 than in 2002. The latter year was characterized by relatively poor spring weather with several cold and rainy periods in March to May (Swiss Meteo, Zürich), and some trees that flowered did not set any fruit at all. In addition, the flowering of individuals was more synchronous among individuals in 2001 than in 2002. However, the flowering period of all individuals surveyed in both populations and both years was overlapping to a certain degree. Hence, no shortage of mating partners should be expected, based on individual flowering periods alone. In the large population Bremlen, the inclement spring weather conditions in 2002 probably also led to a significantly smaller seed set per fruit and to significantly increased mean selfing rates (about $8 \%$ ) as compared to the year 2001 with favourable weather (about 2\% selfing). Surprisingly, this higher selfing rate did not result in a higher $F_{\text {IS }}$ value in the 2002 progeny: the progenies from both years in Bremlen even had negative $F_{\mathrm{IS}}$ values, and the $F_{\mathrm{IS}}$ values of adults and progenies were not different from each other. This could be due to the fact that, despite the increased selfing in 2002, mother trees were fertilized by a similarly large number of father trees in both years.

Our results and those of Oddou-Muratorio et al. (2005) indicate that mating patterns might substantially vary among years with different weather conditions. In particular, selfing was considerably higher in a year with adverse spring weather. It has long been speculated that $S$. torminalis, like other woody Rosaceae (Raspé and Kohn, 2002), possesses a gametophytic self-incompatibility system. Low temperatures can lead to a shortage of compatible pollen due to insect inactivity and, along with increasing age of non-pollinated flowers, to a breakdown of self-compatibility systems (DeNettancourt, 2001). This might explain the higher 2002 selfing rate given the adverse weather conditions during the 2002 flowering period.

It is well known that the position of individuals within forests (e.g., small, suppressed individuals vs dominant canopy trees or forest edge individuals vs individuals in closed forest) affects the flowering intensity, mating success and, thus, the fecundity of individuals of $S$. torminalis and other woody Rosaceae (Oddou-Muratorio et al., 2005; Angelone et al., in press). In other words, light availability promotes flowering. In our study, we found a positive effect of $\mathrm{DBH}$, a common measurement of tree size, on the contribution of father trees to the progenies of particular mother trees in both populations and years. While we found small individuals that flowered $(\mathrm{DBH}=10 \mathrm{~cm})$, only very large individuals of $S$. torminalis $(\mathrm{DBH}>35 \mathrm{~cm})$ had a high probability of flowering. Oddou-Muratorio et al. (2005) also found a significant influence of DBH on mating patterns in S. torminalis. This probably reflects that, in closed forests, only the crowns of large individuals of $S$. torminalis reach into the forest canopy and, therefore, attain regular and intense flowering. Smaller trees only flower if they are in a more open position within stands or at forest edges. The pollen of canopy individuals could also have a higher chance of being distributed by insects, although Kreyer et al. (2004) showed that bumblebees regularly fly through closed forests. The fact that in the large population Bremlen, both $\mathrm{DBH}$ and distance among mates had a significant effect on the relative contribution of father trees to the progeny of particular mother trees in 2001 probably reflects that, in favourable years with a plentiful offer of pollen, distance plays a larger role than in years with unfavourable weather conditions and, hence, a more scattered and less abundant pollen supply. Indeed, Figure 3 shows that pollen dispersal curves varied among years and that mean pollen flow distance was lower in the more favourable year 2001. Similar effects have been shown in tropical tree species, where a distinct effect of distance was found in dense stands, but not so in scattered stands or among single, isolated individuals (White et al., 2002; Latouche-Hallé et al., 2004; Ward et al., 2005).

The above results have important conservation implications. S. torminalis is a tree species that formerly profited from more intense use of forest resources. The former mosaic of coppiced woodland and woodland pasture provided ample habitat patches for this pioneer or early successional species. With the ongoing transformation towards high stands with closed canopies, its populations became smaller and less abundant. Remnant $S$. torminalis trees were dominated by late successional trees, for example, beech and oaks, and ceased to flower and fruit (Barengo et al., 2001; Oddou-Muratorio et al., 
2005; Angelone et al., in press). Current populations might thus form non-viable local populations, although they might survive for extended periods due to $S$. torminalis' ability to propagate clonally (Hoebee et al., 2006). As a consequence, conservation measures should try to mimic former traditional forest structures at a landscape scale (Angelone et al., in press).

\section{Differences between a large, continuous and a small, isolated population}

The population of $S$. torminalis in Wuerholz showed several characteristic attributes of small size and geographical isolation in plants (Young et al., 1996; Frankham et al., 2002; Hamrick, 2004). In particular, it showed a lower number of flowering individuals, reduced flowering intensity and less fruiting than the large, continuous population Bremlen, in the favourable year 2001. The small population Wuerholz also had a significantly lower seed set per fruit. In the year 2002, with unfavourable weather conditions, fruiting was so low that we were unable to sample sufficient seeds for genetic paternity analysis. The reduced mating and fecundity in Wuerholz corresponds to a reproductive Allee effect (Stephens et al., 1999), potentially owing to (compatible) pollen limitation. In accordance, we found that in the small population Wuerholz, mother trees were fertilized by significantly fewer father trees (about five) than mother trees in the large population Bremlen (about 12) and that mean selfing was significantly higher in 2001 (about $30 \%$ vs 2\%, respectively). This was also indicated by the multi-locus outcrossing rate of $t m=0.78$ in Wuerholz. However, it seems that the reproductive Allee effect did not necessarily translate into a substantial genetic Allee effect (Fischer et al., 2000). The $F_{\text {IS }}$ value of the 2001 progeny from Wuerholz was negative (though higher) and not different from the $F_{\text {Is }}$ of the adult population, indicating no departure from HardyWeinberg equilibrium. Also, the $F_{\mathrm{IS}}$ value of the small population Wuerholz did not differ from the $F_{\mathrm{IS}}$ of the large population Bremlen. This negative $F_{\text {IS }}$ value of the progeny in Wuerholz is rather surprising given the substantial selfing rate detected in this population, but can be explained by an otherwise substantial mating among genetically unrelated individuals (no bi-parental inbreeding). In fact, the mother trees in Wuerholz, as well as those in Bremlen, received pollen from $S$. torminalis trees that were scattered over the entire population area. In both populations studied, (almost) the maximum spatial distance among mates was attained, although mean pollen flow distance was smaller in Wuerholz $(59 \mathrm{~m})$ as compared with Bremlen $(119 \mathrm{~m})$ in 2001, owing to the smaller population area of the former. Taken together, this evidence leads to the unexpected conclusion that despite decreased fecundity in the small population of $S$. torminalis, no effective signs of increased genetic inbreeding in the progeny (seed stage) occurred at the population level, at least not in a year with favourable spring weather conditions. In accordance with our results, Stoeckel et al. (2006) also found negative $F_{\text {IS }}$ values of open pollinated progenies in small stands of the self-incompatible woody Rosaceae Prunus avium.

Although difficult to compare because of different methodological and analytical approaches (Sork and
Smouse, 2006), recent genetic studies on contemporary pollen flow in natural populations found that in continuous populations, gene flow by pollen from outside the surveyed area often accounts for about $30 \%$ (Burczyk et al., 2004; Hamrick, 2004; Smouse and Sork, 2004; Ward et al., 2005; Sork and Smouse, 2006). We found similar estimates for our large, continuous population of $S$. torminalis in Bremlen, with mean pollen immigration rates of about $37 \%$ in 2001 and $39 \%$ in 2002. Likewise, Oddou-Muratorio et al. (2005) reported a similar value of $40 \%$ for a large stand of S. torminalis in France.

In marked contrast, however, the small and spatially isolated population Wuerholz only experienced $4 \%$ of contemporary external gene flow by pollen. This foreign pollen must have travelled at least several hundred metres from an isolated individual of $S$. torminalis, but potentially originated from $1.25-6 \mathrm{~km}$ further away. Garcia et al. (2005) found a value of $9.5 \%$ pollen immigration from a distance of $1.5 \mathrm{~km}$ into a population of the insect-pollinated woody Rosaceae Prunus mahaleb. Such limited contemporary gene flow by pollen into a small and isolated stand of an insect-pollinated tree species is well in accordance with theoretical expectations on fragmented populations from conservation biology (Frankham et al., 2002; Hamrick, 2004). However, even if the $4 \%$ gene flow value from Wuerholz seems small, one should recognize that it means that about every twentieth seed in this distinctly isolated population arose as a result of inter-population fertilization over long distances.

\section{Conclusions}

In summary, our study showed clear effects of small population size and geographical isolation in S. torminalis. A small and geographically isolated population harboured a lower percentage of flowering trees, showed less intensive flowering, lower fruiting, fewer seeds per fruit, increased selfing and received less pollen immigration than a large, continuous population of $S$. torminalis. Nevertheless, this did not result in a significantly inbred progeny at the population level. We also showed that flowering and fruiting as well as pollen flow patterns varied among years, the latter being affected by the size of individuals.

However, our study has one major shortcoming. Due to the workload of determining mating patterns through paternity analysis within populations, we compared only one small, isolated population with only one large, continuous population of $S$. torminalis. The study is therefore not replicated at the population level, neither with respect to population size (small vs large) nor with respect to the, here confounded, effect of geographical isolation (isolated vs non-isolated). Nevertheless, the present investigation provides insights into the effects of isolation and population size in a temperate, insectpollinated tree species. Similar studies, most of them also not replicated, have been carried out on tropical tree species from forest remnants (Ward et al., 2005). A potential solution to the problem of replication is to use landscape genetics (Manel et al., 2003; Holderegger et al., in press) in a whole landscape compartment, for example, a valley (Coulon et al., 2006). Such a spatially explicit approach does not need any categorization of populations with respect to size or isolation, but can 
directly make use of the varying levels of spatial isolation and local patch size found in the real-world context.

\section{Acknowledgements}

We thank Sonia Angelone and Kirsti Määttänen for help with data analysis, Michaela Stettler, Stephan Bernhard, Daniela Csencsics and Karin Hilfiker for assistance during fieldwork and Ernst Fürst for stimulating discussions. We also thank the local foresters and forest authorities for the permit to work on their ground. The comments of two anonymous referees and the editor substantially improved the manuscript. Funding was provided by the Swiss Agency for the Environment (BAFU).

\section{References}

Angelone S, Hilfiker K, Holderegger R, Bergamini A, Hoebee SE (in press). Regional processes underlie Sorbus torminalis population dynamics: evidence from molecular genetics and ecological data. Mol Ecol.

Barengo N, Rudow A, Schwab P (2001). Förderung Seltener Baumarten. BUWAL: Bern.

Barrett SCH, Harder LD (1996). Ecology and evolution of plant mating. Trends Ecol Evol 11: 73-79.

Bradshaw RHW (2004). Past anthropogenic influence on European forests and some possible genetic consequences. Forest Ecol Manage 197: 203-212.

Burczyk J, Chybicki IJ (2004). Cautions on direct gene flow estimation in plant populations. Evolution 58: 956-963.

Burczyk J, DiFazio SP, Adams WT (2004). Gene flow in forest trees: how far do genes really travel? Forest Genet 11: 179-192.

Coulon A, Guillet G, Cosson J-F, Angibault JMA, Awagnier MA, Awagnier S et al. (2006). Genetic structure is influenced by landscape features: empirical evidence from a roe deer population. Mol Ecol 15: 11678-16669.

Demesure B, LeGuerroue B, Lucchi G, Prat D, Petit RJ (2000). Genetic variability of a scattered temperate forest tree: Sorbus torminalis L. (Crantz). Ann For Sci 57: 63-71.

DeNettancourt D (2001). Incompatibility and Incongruity in Wild and Cultivated Plants. Springer: Berlin.

Dow BD, Ashley MV (1996). Microsatellite analysis of seed dispersal and parentage of saplings in bur oak, Quercus macrocarpa. Mol Ecol 5: 615-627.

Fahrig L (1997). Relative effects of habitat loss and fragmentation on population extinction. J Wildlife Manage 61: 603-610.

Fischer M, Van Kleunen M, Schmid B (2000). Genetic Allee effects on performance, plasticity and developmental stability in a clonal plant. Ecol Letters 3: 530-539.

Frankham RJ, Ballou JD, Briscoe DA (2002). Introduction to Conservation Genetics. Cambridge University Press: Cambridge.

Garcia C, Arroyo M, Godoy JA, Jordano P (2005). Mating patterns, pollen dispersal, and the ecological maternal neighbourhood in a Prunus mahaleb L. population. Mol Ecol 14: $1821-1830$.

Hamrick JL (2004). Response of forest trees to global environmental changes. Forest Ecol Manage 197: 323-375.

Hoebee SE, Menn C, Rotach P, Finkeldey R, Holderegger R (2006). Spatial genetic structure of Sorbus torminalis: the extent of clonal reproduction in natural stands of a rare tree species with a scattered distribution. Forest Ecol Manage 226: 1-8.

Holderegger R (1997). Recent perspectives in conservation biology of rare plants. Bull Geobot Inst ETH 63: 109-116.

Holderegger R, Gugerli F, Scheidegger C, Taberlet P (in press). Integrating population genetics with landscape ecology to infer spatio-temporal processes. In: Kienast F, Gosh R,
Wildi O (eds). A Changing World: Challenges for Landscape Research. Springer: Dordrecht.

Huenneke LF (1991). Ecological implications of genetic variation in plant populations. In: Falk DA, Holsinger KE (eds). Genetics and Conservation of Rare Plants. Oxford University Press: Oxford. pp 31-44.

Kreyer D, Oed A, Walter-Hellwig K, Frankl R (2004). Are forests potential landscape barriers for foraging bumblebees? Landscape scale experiments with Bombus terrestris agg. and Bombus pascuorum (Hymenoptera, Apidae). Biol Conserv 116: 111-118.

Kutzelnigg H (1995). Sorbus. In: Conert HJ, Jäger EJ, Kadereit JW, Schultze-Motel W, Wagenitz G, Weber HE (eds). Gustav Hegi, Illustrierte Flora von Mitteleuropa IV(2B). Blackwell: Berlin. pp 328-385.

Latouche-Hallé C, Ramboer A, Badou E, Caron H, Kremer A (2004). Long-distance pollen flow and tolerance to selfing in a neotropical tree species. Mol Ecol 13: 1055-1064.

Lienert J (2004). Habitat fragmentation effects on fitness of plant populations - a review. J Nature Conserv 12: 53-72.

Liljefors A (1955). Cytological studies in Sorbus. Acta Horti Berg 17: 47-113.

Manel S, Schwartz MK, Luikart G, Taberlet P (2003). Landscape genetics: combining landscape ecology and population genetics. Trends Ecol Evol 18: 185-197.

Marshall TC, Slate J, Kruuk LEB, Pemberton JM (1998). Statistical confidence for likelihood-based paternity inference in natural populations. Mol Ecol 7: 639-655.

Oddou-Muratorio S, Aligon C, Decoocq S, Plomion C, Lamant T, Demesure B (2001c). Microsatellite primers for Sorbus torminalis and related species. Mol Ecol Notes 1: 297-299.

Oddou-Muratorio S, Guesnet D, Ozdemir E, Petit RJ, Demesure B (2001a). Patterns of seed dispersal in a scattered forest tree species (Sorbus torminalis) based on multi-scale investigation of population genetic structure for chloroplast DNA. In: Müller-Starck G, Schubert R (eds). Genetic Responses of Changing Environmental Conditions. Kluwer: Dordrecht. pp 271-280.

Oddou-Muratorio S, Houet M-L, Demesure-Musch B, Austerlitz F (2003). Pollen flow in the wild service tree, Sorbus torminalis (L.) Crantz. I. Evaluating the paternity analysis procedure in continuous populations. Mol Ecol 12: 3427-3439.

Oddou-Muratorio S, Klein EK, Austerlitz F (2005). Pollen flow in the wild service tree, Sorbus torminalis (L.) Crantz. II. Pollen dispersal and heterogeneity in mating success inferred from parent-offspring analysis. Mol Ecol 14: 4441-4452.

Oddou-Muratorio S, Petit RJ, LeGuerroue B, Guesnet D, Demesure B (2001b). Pollen- versus seed-mediated gene flow in a scattered forest tree species. Evolution 55: 1123-1135.

Raspé O, Kohn JR (2002). S-allele diversity in Sorbus aucuparia and Crataegus monogyna (Rosaceae: Maloideae). Heredity 88: 458-465.

Rice WR (1989). Analysing tables of statistical tests. Evolution 43: 223-225.

Ritland K (2002). Extensions of models for the estimation of mating systems using $n$ independent loci. Heredity 88: 221-228.

Slavov GT, Howe GT, Gyaourowa AV, Birkes DS, Adams SWT (2005). Estimating pollen flow using SSR markers and paternity exclusion: accounting for mistyping. Mol Ecol 14: 3109-3121.

Smouse PE, Sork VL (2004). Measuring pollen flow in forest trees: an exposition of alternative approaches. Forest Ecol Manage 197: 21-38

Sork V, Smouse PE (2006). Genetic analysis of landscape connectivity in tree populations. Landsc Ecol 21: 821-836.

Sork VL, Nason J, Campbell DR, Fernandez JF (1999). Landscape approaches to historical and contemporary gene flow in plants. Trends Ecol Evol 14: 219-224.

Stephens PA, Sutherland WJ, Freckleton RP (1999). What is the Allee effect? Oikos 87: 185-190. 
Stoeckel S, Grange J, Fernández-Manjarres JF, Bilger I, FrascariaLacoste N, Mariette S (2006). Heterozygote excess in a selfincompatible and partially clonal forest tree species. Mol Ecol 15: 2109-2118.

Streiff R, Ducousso A, Lexer C, Steinkellner H., Gloessl J, Kremer A (1999). Pollen dispersal inferred from paternity analysis in a mixed oak stand of Quercus robur L. and $Q$. petraea (Matt.) Liebl. Mol Ecol 8: 831-841.

Warburg EF, Kàrpàti ZE (1968). Sorbus. In: Tutin TG, Heywood $\mathrm{VH}$, Burges NA, Moore DM, Valentine DH, Walters SM, Webb DA (eds). Flora Europea 2. Cambridge University Press: London. pp 67-71.

Ward M, Dick CW, Gribel R, Lowe AJ (2005). To self, or not to self. A review of outcrossing and pollen-mediated gene flow in neotropical trees. Heredity 95: 246-254.
White M, Boshier DH, Powell H (2002). Increased pollen flow counteracts fragmentation in a tropical dry forest: an example from Swietenia humilis Zuccarini. Proc Natl Acad Sci USA 99: 2038-2042.

Willi Y, Fischer M (2005). Genetic rescue in interconnected populations of small and large size of the self-incompatible Ranunculus reptans. Heredity 95: 437443.

Wohlgemuth T, Bürgi M, Scheidegger C, Schütz M (2002). Dominance reduction of species through disturbance - a proposed management principle for Central European forests. Forest Ecol Manage 166: 1-15.

Young A, Boyle T, Brown T (1996). The population genetic consequences of habitat fragmentation for plants. Trends Ecol Evol 11: 413-418. 